\title{
Evaluation of atherogenic index of plasma levels at hypertensive patients
}

\section{Hipertansif hastalarda plazma aterojenik indeks düzeylerinin incelenmesi}

\author{
Özge Turgay Yıldırım ${ }^{1}$, Ercan Akşit ${ }^{2}$, Fatih Aydın ${ }^{1}$, Ayşe Hüseyinoğlu Aydın ${ }^{1}$
}

\section{Abstract}

Aim: Hypertension is a major risk factor for cardiovascular system. Recent studies showed that atherogenic index of plasma (AIP) has a strong association with cardiovascular morbidity, all-cause mortality, atherosclerosis and severity of coronary artery disease. It also has a relationship with endothelial damage in hypertensive patients. With this study we aim to investigate the association between AIP and hypertension.

Methods: A total of 213 patients were enrolled for the study. Patients with previous hypertension, nephrotic syndrome, diabetes mellitus, hypotiroidism diagnosis, patients under statin treatment and patients under 18 years of age were excluded. Diagnosis of hypertension and blood pressure (BP) results were obtained with 24-hour ambulatory blood pressure monitoring (ABPM). AIP was defined as the logarithmic transformation of the triglyceride to high-density lipoprotein-cholesterol ratio.

Results: Mean age of the population was $49.2 \pm 14.6$ years and $41.8 \%(n=89)$ was male. According to 24 -hour ABPM results, AIP was positively correlated with day-time systolic blood pressure (SBP) $(r=0.244, p<0.001)$, day-time diastolic blood pressure (DBP) $(r=0.276, p<0.001)$, night-time SBP $(r=0.259, p<0.001)$, night-time $\operatorname{DBP}(r=0.299, p<0.001)$, average SBP $(r=0.213, p=0.002)$ and average DBP $(r=0.296, p<0.001)$. AIP was also increased in hypertensive patients compared to normotensive subjects $(\mathrm{p}=0.001)$.

Conclusion: Results of our study showed that AIP was positively correlated with blood pressure and statistically higher in patients with hypertension.

Keywords: atherogenic index of plasma, hypertension, blood pressure, 24-hour ambulatory blood pressure monitoring.

\section{Öz}

Amaç: Hipertansiyon, kardiyovasküler sistem için önemli risk faktörlerinden biridir. Son dönemde yapılan araştırmalar, plazma aterojenik indeksinin (PAİ) kardiyovasküler morbidite, tüm nedenlere bağlı ölüm, ateroskleroz ve koroner arter hastalığının ciddiyeti ile güçlü bir ilişkisi olduğu gösterilmiştir. Ayrıca hipertansif hastalarda endotel hasarı ile ilişsisi vardır. Biz bu çalışma ile PAİ ile hipertansiyon arasındaki ilişkiyi araștırmayı amaçladık.

Yöntemler: Çalışmaya toplam 213 hasta alındı. Daha önce hipertansiyon, nefrotik sendrom, diyabetes mellitus, hipotiroidizm tanısı olan, statin tedavisi alan ve 18 yaşın altındaki hastalar çalışmadan dışlandı. 24 saatlik ambulatuvar kan basıncı ölçümü ile hipertansiyon tanısı ve kan basıncı (KB) sonuçları alındı. PAİ, trigliseritin yüksek yoğunluklu lipoprotein kolesterol oranının logaritmik dönüşümü olarak tanımlandı.

Bulgular: Çalışmaya katılan hastaların yaş ortalaması 49,2 \pm 14,6 yıl idi ve \% 41,8'ü (n= 89) erkekti. 24 saatlik ambulatuar kan basıncı ölçümü sonuçlarına göre, PAİ, gündüz sistolik kan basıncı (SKB) $(r=0,244, p<0,001)$ gündüz diyastolik kan basıncı (DKB) $(r=0,276, p<0,001)$, gece $\operatorname{SBP}(r=0,259, p<0,001)$, gece DKB $(r=0,299$, $\mathrm{p}<0,001)$, ortalama SKB $(r=0.213, p=0,002)$ ve ortalama DKB $(r=0,296, p<0,001)$ ile pozitif olarak korele idi. Hipertansif hastalarda PAİ normotansif hastalara göre istatistiksel olarak anlamlı düzeyde yüksekti $(\mathrm{p}=0,001)$.

Sonuç: Çalışmamızın sonucunda PAİ'nin kan basıncıyla pozitif olarak korele olduğu ve PAİ değerlerinin hipertansif hastalarda istatistiksel açıdan anlamlı şekilde yüksek olduğunu saptamıştır.

Anahtar kelimeler: Plazma aterojenik indeksi, hipertansiyon, kan basıncı, 24 saatlik ambulatuar kan basınc ölçümü.
${ }^{1}$ Eskisehir State Hospital, Department of Cardiology, Eskisehir, Turkey.

${ }^{2}$ Canakkale Onsekiz Mart University Faculty of Medicine, Department of Cardiology, Canakkale, Turkey.

Ethics Committee Approval: The study wass approved by the local ethical authority (17.10.2018011-KAEK-27/2018-1800139853).

Etik Kurul Onayı: Çalışma lokal etik komite tarafindan onaylanmıștır 17.10.2018-011-KAEK27/2018-1800139853).

Conflict of Interest: No conflict of interest was declared by the authors.

Çıkar Çatışması: Yazarlar çıkar çatışması bildirmemișlerdir.

Financial Disclosure: The authors declared that this study has received no financial support.

Finansal Destek: Yazarlar bu çalıșma için finansal destek almadıklarını beyan etmişlerdir.

Geliş Tarihi / Received: 13.05.2019

Kabul Tarihi / Accepted: 09.07.2019 Yayın Tarihi / Published: 01.08.2019

Sorumlu yazar / Corresponding author:

Özge Turgay Yıldırım

71 Evler Mahallesi, Şht. Mustafa Türker Sk. No:30 Eskişehir Şehir Hastanesi Kardiyoloji Polikliniği,

Odunpazarı/Eskişehir, Turkey.

Postal code: 26080

e-posta: ozgeturgay@gmail.com Tel/Phone: +90 5326876626

Copyright $\odot$ ACEM 


\section{Introduction}

Hyperlipidemia is a major risk factor for development of vascular diseases and atherosclerosis [1]. Especially low levels of high-density lipoprotein cholesterol (HDL-C) and high levels of triglyceride and low-density lipoprotein cholesterol (LDL-C) are considered as mediators and markers for cardiovascular diseases [2]. Recent studies suggested atherogenic index of plasma (AIP) which is the logarithmic transformation of triglyceride to HDL-C ratio, can be used as a new marker for atherosclerosis and cardiovascular diseases [3-5]. AIP is associated with low LDL-C particle size and is suggested to be a surrogate for small dense LDL-C particles [5]. Dobiasova et al. reported that AIP can be used as an indicator for cardiovascular risk [6]. AIP also predicts type 2 diabetes mellitus development risk [7].

It is also important to determine the effects of the newly identified risk factors such as AIP to other major diseases such as hypertension. It was found that AIP was correlated with microalbuminurea in hypertensive patients [8]. Onat et al. [9] found out that AIP was increased with higher blood pressure. But the literature research revealed no direct study comparing AIP levels with hypertensive and normal population. With this study we aim the determine the relationship between AIP and blood pressure and to find out if there was a difference in AIP levels between newly diagnosed hypertensive patients and normal population via 24-h ambulatory blood pressure monitoring (ABPM) results.

\section{Material and methods}

A total of 213 patients whom 24-hour ABPM was applied between September 2017 and September 2018 were evaluated retrospectively. The study was approved by the local ethics committee (Çanakkale Onsekiz Mart University Ethics Committee, 17.10.2018-011-KAEK-27/2018-1800139853). The study was performed in accordance with Declaration of Helsinki. Due to the retrospective design of the study, written consent from the patients could not be taken.

Consecutive patients who admitted to cardiology outpatient clinic with medical indication for 24-hour ABPM were included for the study. Patients with previous hypertension, nephrotic syndrome, diabetes mellitus, hypotiroidism diagnosis, patients under statin treatment and patients under 18 years of age were excluded.

Demographic (age and sex), clinical and echocardiographic data were obtained from hospital medical records retrospectively. Modified Simpson's method was used for the calculation of left ventricular ejection fraction. Fasting blood glucose $(\mathrm{mg} / \mathrm{dl})$, blood urea nitrogen $(\mathrm{mg} / \mathrm{dl})$, creatinine $(\mathrm{mg} / \mathrm{dl})$, HDL-C $(\mathrm{mg} / \mathrm{dl})$, LDL-C $(\mathrm{mg} / \mathrm{dl})$, triglyceride $(\mathrm{mg} / \mathrm{dl})$, hemoglobin $(\mathrm{g} / \mathrm{dl})$, leukocyte $\left(\times 10^{3} / \mathrm{mm}^{3}\right)$ and platelet $\left(\mathrm{x} 10^{3} / \mathrm{mm}^{3}\right)$ values were obtained from the laboratory records of the hospital. The fasting results of triglyceride and HDL-C levels were used for calculation of AIP. The AIP was defined as the base 10 logarithm of the triglyceride to HDL-C ratio.

Patients with high ABPM results (waking ambulatory SBP/DBP >135/85 mmHg and/or sleeping SBP/DBP >120/70 $\mathrm{mmHg}$ ) were categorized as hypertensive.

\section{Statistical Analysis}

Data were analyzed using SPSS 20.0 (IBM SPSS Ver. 20.0, IBM Corp, Armonk NY, USA). Data are presented as mean \pm standard deviation (SD) and as proportions for categorical variables. The t-test or Chi-square test was used for comparisons of continuous and categorical variables, respectively.
Distribution of data for normality was tested by the ShapiroWilk test and homogeneity of group variances were tested by the Levene test. For the parameters which are not normally distributed, Mann Whithey U test is used. Pearson correlation test was used for correlation analysis. Binary logistic regression analysis was performed to identify associations of hypertension with clinical and laboratory parameters of the patients. $\mathrm{P}$ values $<0.05$ were considered statistically significant.

\section{Results}

A total of 213 patients were enrolled for the study. Mean age of the population was $49.2 \pm 14.6$ years and $41.8 \%$ $(n=89)$ was male. Hypertensive and normotensive study groups were formed according to 24-hour ABPM results. Hypertensive patients constituted $54.0 \%(n=115)$ of the study group and $46.0 \%$ of the study group was normotensive $(n=98)$. The groups were statistically similar in terms of age $(\mathrm{p}=0.060)$, gender $(\mathrm{p}=0.792)$ and left ventricular ejection fraction $(\mathrm{p}=0.605)$ (Table 1).

Table 1: Comparison of the baseline characteristics and laboratory results of the study groups.

\begin{tabular}{|c|c|c|c|}
\hline Variables & $\begin{array}{c}\text { Hypertensive } \\
\text { Patients }(n=115)\end{array}$ & $\begin{array}{l}\text { Normotensive } \\
\text { Group }(n=98)\end{array}$ & $\mathrm{p}$ \\
\hline Sex/Male $^{\mu}$ & $49(42.6)$ & $40(40.8)$ & 0.792 \\
\hline Age $(\text { years })^{¥}$ & $50.9 \pm 13.8$ & $47.1 \pm 15.2$ & 0.060 \\
\hline $\operatorname{LVEF}(\%)^{¥}$ & $57.9 \pm 2.2$ & $58.0 \pm 2.6$ & 0.605 \\
\hline $\mathrm{FBG}(\mathrm{mg} / \mathrm{dL})^{*}$ & $93.7 \pm 11.0$ & $91.9 \pm 10.4$ & 0.233 \\
\hline BUN $(\mathrm{mg} / \mathrm{dL})^{¥}$ & $14.3 \pm 4.3$ & $13.1 \pm 4.4$ & 0.068 \\
\hline Creatinine $(\mathrm{mg} / \mathrm{dL})^{*}$ & $0.8 \pm 0.1$ & $0.7 \pm 0.1$ & 0.184 \\
\hline HDL-C $(\mathrm{mg} / \mathrm{dL})^{\#}$ & $50.9 \pm 13.3$ & $53.6 \pm 11.3$ & 0.125 \\
\hline LDL-C $(\mathrm{mg} / \mathrm{dL})^{\ddagger}$ & $129.6 \pm 36.8$ & $121.9 \pm 39.3$ & 0.147 \\
\hline Triglyceride $(\mathrm{mg} / \mathrm{dL})^{¥}$ & $161.8 \pm 97.7$ & $126.6 \pm 65.8$ & 0.002 \\
\hline $\mathrm{Hb}(\mathrm{g} / \mathrm{dL})^{¥}$ & $14.5 \pm 1.6$ & $13.9 \pm 1.9$ & 0.021 \\
\hline Leukocyte $\left(\mathrm{x} 10^{3} / \mathrm{mm}^{3}\right)^{¥}$ & $7.8 \pm 1.9$ & $7.4 \pm 1.9$ & 0.165 \\
\hline Platelets $\left(\times 10^{3} / \mathrm{mm}^{3}\right)^{¥}$ & $275.1 \pm 64.6$ & $268.6 \pm 64.6$ & 0.473 \\
\hline $\mathrm{AIP}^{¥}$ & $0.45 \pm 0.30$ & $0.33 \pm 0.26$ & 0.001 \\
\hline
\end{tabular}

$\mu$ : $\mathrm{n}(\%),{ }^{\ddagger}:$ mean \pm standard deviation.

BUN, blood urea nitrogen; FBG, fasting plasma glucose; $\mathrm{Hb}$, hemoglobin; HDL-C, high density lipoprotein cholesterol; LDL-C, low density lipoprotein cholesterol; LVEF, left ventricular ejection fraction; AIP: Atherogenic index of plasma.

There were no significant difference in fasting blood glucose, blood urea nitrogen, creatinine, HDL-C, LDL-C, leukocyte and platelet values between the groups $(\mathrm{p}>0.05)$. Hemoglobin $(\mathrm{p}=0.021)$ and triglyceride $(\mathrm{p}=0.002)$ values were higher in hypertensive patients compared to normal population. AIP was also increased in hypertensive patients $(\mathrm{p}=0.001)$ (Table $1)$. 
hypertension

According to Pearson correlation analysis, AIP was positively correlated with day-time SBP $(r=0.244, \mathrm{p}<0.001)$, daytime DBP $(\mathrm{r}=0.276, \mathrm{p}<0.001)$, night-time SBP $(\mathrm{r}=0.259$, $\mathrm{p}<0.001)$, night-time DBP $(\mathrm{r}=0.299, \mathrm{p}<0.001)$, average SBP $(\mathrm{r}=0.213, \mathrm{p}=0.002)$, average DBP $(\mathrm{r}=0.296, \mathrm{p}<0.001)$ (Table 2).

Table 2: Pearson correlation analysis of AIP and 24-hour ABPM values. AIP

\begin{tabular}{lcc}
\cline { 2 - 3 } Variables & $\mathrm{r}$ & $\mathrm{p}$ \\
\hline Day SBP & 0.244 & $<0.001$ \\
Day DBP & 0.276 & $<0.001$ \\
Night SBP & 0.259 & $<0.001$ \\
Night DBP & 0.299 & $<0.001$ \\
Average SBP & 0.213 & 0.002 \\
Average DBP & 0.296 & $<0.001$ \\
\hline
\end{tabular}

AIP: Atherogenic index of plasma, ABPM: ambulatory blood pressure monitoring, SBP: Systolic blood pressure, DBP: Diastolic blood pressure.

Based on the sex distribution, in male subjects; AIP was positively correlated with day-time $\operatorname{SBP}(\mathrm{r}=0.230, \mathrm{p}=0.032)$, daytime DBP $(\mathrm{r}=0.296, \mathrm{p}=0.005)$, night-time DBP $(\mathrm{r}=0.285$, $\mathrm{p}=0.007)$ and average DBP $(\mathrm{r}=0.319, \mathrm{p}=0.003)$. There was no correlation with AIP and night-time SBP $(r=0.193, p=0.074)$ and average SBP ( $\mathrm{r}=0.159, \mathrm{p}=0.142)$. For female subjects, AIP was positively correlated with day-time $\operatorname{SBP}(r=0.237, \mathrm{p}=0.008)$, daytime DBP $(r=0.228, \quad p=0.011)$, night-time SBP $(r=0.309$, $\mathrm{p}=0.001)$, night-time DBP $(\mathrm{r}=0.297, \mathrm{p}=0.001)$, average SBP $(\mathrm{r}=0.261, \mathrm{p}=0.004)$ and average $\mathrm{DBP}(\mathrm{r}=0.252, \mathrm{p}=0.005)$.

Binary logistic regression analysis to investigate which variables have a significant effect on hypertension showed that AIP (odds ratio, 4.108; 95\% confidence interval, 1.436-11.754, $\mathrm{p}$ $=0.008$ ), hemoglobin (odds ratio, 1.206; 95\% confidence interval, 1.013-1.434, $\mathrm{p}=0.035$ ) and age (odds ratio, $1.023 ; 95 \%$ confidence interval, 1.003-1.045, $\mathrm{p}=0.027)$ had explanatory power on hypertension diagnosis (Table 3 ).

Table 2: Binary logistic regression analysis results

\begin{tabular}{|c|c|c|c|c|c|c|}
\hline \multirow[t]{2}{*}{ Variables } & \multirow[t]{2}{*}{ Beta } & \multirow[t]{2}{*}{$\begin{array}{l}\text { Std. } \\
\text { Error }\end{array}$} & \multirow[t]{2}{*}{$\mathrm{p}$} & \multirow[t]{2}{*}{$\begin{array}{l}\text { Exp. } \\
\text { (Beta) }\end{array}$} & \multicolumn{2}{|c|}{$95 \% \mathrm{CI}$} \\
\hline & & & & & Lower & Upper \\
\hline Age & 0.023 & 0.010 & 0.027 & 1.023 & 1.003 & 1.045 \\
\hline AIP & 1.413 & 0.536 & 0.008 & 4.108 & 1.436 & 11.754 \\
\hline Hemoglobin & 0.187 & 0.089 & 0.035 & 1.206 & 1.013 & 1.434 \\
\hline Constant & -4.224 & 1.445 & 0.003 & 0.015 & & \\
\hline
\end{tabular}

AIP: Atherogenic index of plasma, CI: confidence interval, Std; standard.

\section{Discussion}

In our study we found out that AIP is significantly higher in hypertensive patients compared to normotensive subjects. Also AIP is positively correlated with day-time systolic and diastolic BP, night-time systolic and diastolic BP, all-day systolic and diastolic BP. Binary logistic regression analysis revealed that AIP was associated with incidence of hypertension diagnosis.

Traditionally atherogenic lipid profile consists of increased triglyceride, LDL-C, total cholesterol and decreased HDL-C. At 1999, Connelly et al. [10] found out that smoking, diabetes, and hypertension were more common at high triglyceride and low HDL-C patients. Studies like this one showed the importance of combined effect of triglyceride and HDL-C values. Combining two lipid profile measurements and taking ratio of triglyceride to HDL-C has been shown to be higher in patients with myocardial infarction [11]. But this ratio lacks the normative distribution. The logarithm of this ratio corrects the lack of normative distribution and demonstrates a correlation with smaller LDL particles and increased fractional esterification rate which is an index for lecithin cholesterol acyltransferase activity [5]. Increased triglyceride and decreased HDL-C values shows oxidative stress and low grade inflammation and because of these effects, AIP has been shown to be associated with metabolic syndrome [9, 12].

Dobiasova et al. [5] showed the correlation between AIP and LDL-C particle size and since then studies have been performed to investigate the relationship between AIP and cardiovascular diseases. Later on AIP has been proven to be an indicator for cardiovascular risk [6]. It has a strong association with cardiovascular morbidity, all-cause mortality, atherosclerosis and severity of coronary artery disease $[4,9,13-$ 15] AIP also associated with major risk factors of cardiovascular diseases. For example AIP was also found to be associated with the risk of diabetes mellitus [7]. Moura Rdo et al. [8] showed that AIP is also associated with microalbuminuria in hypertensive patients which may suggest that AIP also associated with endothelial damage. Onat et al. [9] showed the relationship of AIP with high blood pressure and diabetes. In this study blood pressure was measured in the clinic and data was obtained by the mean of two recordings at least 3 minutes apart. In our study we evaluated patients with 24-h ABPM. Patients with previous hypertension diagnosis or under hypertensive medication treatment were excluded and we found that all parameters of 24h ABPM results were correlated with AIP values. Ours and previous studies show that AIP is associated with blood pressure and hypertension diagnosis.

It is known that prevalance of hypertension increases with age [16]. We also found out that age along with AIP and hemoglobin had explanatory power on hypertension. Previously Shimizu et al. reported positive association between hemoglobin levels and hypertension risk [17]. Krishnamoorthy et al. [18] stated that hypertension is more prevalent in polycythemia patients. Also during pregnancy, hemoglobin concentrations are significantly increased at pregnancy induced hypertension patients [19]. When previous studies are examined, it was expected to found the association between hemoglobin levels, age and hypertension and our study supports these results.

Major limitation for this study was the small number of the patients. Further studies with large sample size must be performed to evaluate the effects of AIP on both hypertension and its complications to improve our knowledge on these issues. Also, this study was conducted at one center and the study population represented a limited population. Similar multicenter studies must be conducted to confirm our results.

In conclusion, AIP is higher in patients with hypertension and correlated with day-time, night time and all day systolic and diastolic blood pressure values.

\section{References}

1. Kwiterovich PO Jr. Lipoprotein heterogeneity: diagnostic and therapeutic implications. Am J Cardiol. 2002;90:1i-10i.

2. NIH Consensus conference. Triglyceride, high-density lipoprotein, and coronary heart disease. NIH Consensus Development Panel on Triglyceride, High-Density Lipoprotein, and Coronary Heart Disease. JAMA. 1993;269:505-10.

3. Shen S, Lu Y, Qi H, Li F, Shen Z, Wu L, et al. Association between ideal cardiovascular health and the atherogenic index of plasma. Medicine (Baltimore). 2016;95:e3866.

4. Niroumand S, Khajedaluee M, Khadem-Rezaiyan M, Abrishami M, Juya M, Khodaee G, et al. Atherogenic index of plasma (AIP):a marker of cardiovascular disease. Med J Islam Repub Iran. 2015;29:240.

5. Dobiásová M, Frohlich J. The plasma parameter log (TG/HDL-C) as an atherogenic index: correlation with lipoprotein particle size and 
esterification rate in apoB-lipoprotein-depleted plasma (FER(HDL)). Clin Biochem. 2001;34:583-8.

6. Dobiasova M. AIP-atherogenic index of plasma as a significant predictor of cardiovascular risk: from research to practice. Vnitr Lek. 2006;52:64-71.

7. Zhu XW, Deng FY, Lei SF. Meta-analysis of atherogenicindex of plasma and other lipid parameters in relation to risk of type2 diabetes mellitus. Prim Care Diabetes. 2015;9:60-7.

8. Moura Rdo S, Vasconcelos DF, Freitas E, Moura FJ, Rosa TT, Veiga JP. Cystatin C, CRP, log TG/HDLc and metabolic syndrome are associated with microalbuminuria in hypertension. Arq Bras Cardiol. 2014;102:54-9.

9. Onat A, Can G, Kaya H, Hergenç G. "Atherogenic index of plasma" ( $\log 10$ triglyceride/high-density lipoprotein-cholesterol) predicts high blood pressure, diabetes, and vascular events. .J Clin Lipidol. 2010;4:8998 .

10. Connelly PW, Petrasovits A, Stachenko S, MacLean DR, Little JA, Chockalingam A. Prevalence of high plasma triglyceride combined with low HDL-C levels and its association with smoking, hypertension, obesity, diabetes, sedentariness and LDL-C levels in the Canadian population. Canadian Heart Health Surveys Research Group. Can J Cardiol. 1999;15:428-33.

11. Gaziano JM, Hennekens CH, O’Donnell CJ, Breslow JL, Buring JE. Fasting triglycerides, high-density lipoprotein and the role of myocardial infarction. Circulation. 1997;96:2520-5.

12. McLaughlin T, Abbasi F, Cheal K, Chu J, Lamendola C, Reaven G. Use of metabolic markers to identify overweight individuals who are insulin resistant. Ann Intern Med. 2003;139:802-9.

13. Yildiz G, Duman A, Aydin H, Yilmaz A, Hür E, Mağden K, et al. Evaluation of association between atherogenic index of plasma and intimamedia thickness of the carotid artery for subclinic atherosclerosis in patients on maintenance hemodialysis. Hemodial Int. 2013;17:397405.

14. Dobiásová M, Frohlich J, Sedová M, Cheung MC, Brown BG. Cholesterol esterification and atherogenic index of plasma correlate with lipoprotein size and findings on coronary angiography. J Lipid Res. 2011;52:566-71.

15. Grammer TB, Kleber ME, März W, Silbernagel G, Siekmeier R, Wieland $\mathrm{H}$, et al. Low-density lipoprotein particle diameter and mortality:The Ludwigshafen risk and cardiovascular health study. Eur Heart J. 2015;36:31-8.

16. Robles NR, Macias JF. Hypertension in elderly. Cardiovasc Hematol Agents Med Chem. 201512:136-45.

17. Shimizu Y, Nakazato M, Sekita T, Kadota K, Arima K, Yamasaki H, et al. Association between the hemoglobin levels and hypertension in relation to the BMI status in a rural Japanese population: the Nagasaki Islands Study. Intern Med. 2014;53:435-40.

18. Krishnamoorthy P, Gopalakrishnan A, Mittal V, Kalla A, Slipczuk L, Rangaswami J, et al. Gaisböck syndrome (polycythemia and hypertension) revisited: results from the national inpatient sample database. J Hypertens. 2018;36:2420-4.

19. Huisman A, Aarnoudse JG. Increased $2 \mathrm{Nd}$ Trimester Hemoglobin Concentration in Pregnancies Later Complicated by Hypertension and Growth Retardation: Early Evidence of a Reduced Plasma Volume. Acta Obstet Gynecol Scand. 1986;65:605-8. 